Acta Horticulturae et Regiotecturae 1

Nitra, Slovaca Universitas Agriculturae Nitriae, 2019, pp. 8-13

\title{
SACRED LANDSCAPES IN GALICIA: SMALL RELIGIOUS ARCHITECTURE AND SYMBOLISM
}

\author{
Pedro CALAZA-MARTíNEZ,* Nuria FREIRE-GONZÁLEZ, Camilo BLANCO-PAMPÍN
}

Galician Landscape School, Spain

\begin{abstract}
Cultural landscapes are multi-layered entities that constantly endure changes and transformations, especially in Europe due to its ancient history and anthropized nature, which reveals itself not only in physical elements, but also through immaterial heritage. This paper aims to analyse the connection between sacred landscapes, small religious architecture and folklore, focusing on the origin and transformations of several places in Galicia (northwest of Spain). Galicia is defined by its rich flora and fauna, a management of its land based on smallholding and the social idiosyncrasy of its people, defined by strong symbolism and the religious tradition that is reflected in a great amount of small sacred architecture. All this provide a paradigmatic territory for this research, allowing an approach to the case studies from the point of view of landscape architecture, assessing the small sacred architecture elements, their background, symbolism and associated vegetation. It is worth mentioning that, although vegetation had a very strong meaning and symbolism in the sacred history of Galicia, nowadays it only appears in $26 \%$ of the analysed case studies.
\end{abstract}

Keywords: small sacred architecture, cultural landscape, immaterial heritage, Galicia, trees

The European territory is immensely rich in terms of cultural landscape, due to the fact that it has been inhabited since ancient times. Anthropization reaches every place, given the great number of civilizations that have lived and transformed this territory over time, adapting it to their advantage in order to survive. This phenomenon has been addressed by some authors referring to it as rewriting landscape (Pracero et al., 1998). Consequently, from a landscape architecture point of view, territory is often explained as a palimpsest that is made of many layers, both physical and intangible. These layers create the genius loci of a place, which is highly related to cultural heritage (Norberg-Schulz, 1980; Roger, 1997). The identity of places is thereby influenced by the way people see them, thus creating the immaterial landscape of each territory that reveals itself in memory and folklore, and is frequently linked to physical elements such as small sacred architecture.

Then again, it is possible to identify common patterns in the way some spaces are associated with certain symbolisms, which appear all over Europe. This leads to the thought that there might be some sort of special condition that imbues specific landscapes, making them more capable of inspiring or reaching human subconscious. In fact, some well-known sacred places are spaces with exceptional landscape qualities as the Mont Saint Michel (France) or Stonehenge (UK). Some of them remain, as the latter, pretty unchanged, but others have been constantly modified, making it more difficult to read the past layers, but at the same time enriching the landscape experience.

Among all the agents that have transformed and modified landscapes over the years, Christianity is perhaps the one that has most influenced the physical space as well as the immaterial heritage. The Christianisation phenomenon involves a change of meaning, adding old beliefs and traditions to a new socio-ideological order (Pracero et al., 1998). Frequently, a connection can be found between landscape, sacred symbolism and Christianity in religious architecture. For example, in the Iberian Peninsula many places of pilgrimage to the Virgin are related to landmarks linked to pre-Christian sacred places, like the Virgin of Covadonga (Spain) or the Virgin of Fatima (Portugal). The study of these places has been so far approached from very different points of view, from a historical to an archaeological or architectural perspective. However, in landscape architecture, it is very important to study the different layers that create a specific landscape, both material and immaterial, getting to know its past in order to plan its future. That also applies to some of the spaces surrounding small sacred architecture, where the historical and present symbolisms are frequently linked to the physical remains. This paper aims to provide insight on this matter, studying places where the connections between landscape, symbolism and sacred architecture are most enhanced.

To that purpose, the connection between physical spaces and immaterial heritage needs to be addressed, taking into account that Christian ideas are part of a syncretism where other ingredients appear, such as beliefs, superstitions, magic, myth, ritual and symbol (Lisón, 1974), and amongst all of them, death is a central subject. Death is a mystery that has always caused all sorts of superstitions and beliefs in all cultures, especially in some areas due to the idiosyncrasy, the spatial configuration of landscape or other cultural facts such as Celtic origins.

Contact address: Pedro Calaza Martínez, Galician Landscape School, Salvador Allende 92, Oleiros, A Coruña, Spain, e-mail: calaza@iies.es 
This is the case of Galicia (Finis Terrae by the Romans), a region with isolated and dispersed small villages along hostile valleys where these beliefs were strengthened, providing a paradigmatic territory in terms of connection between landscape, sacred symbolism and Christian worship.

\section{Material and methods}

In order to analyse small sacred architecture in Galicia (northwest Spain) from a landscape architecture perspective, based on the study of both physical context and immaterial heritage, it was necessary to select case studies that represented this connection between landscape, symbolism and sacred architecture in different areas of the Galician territory. Every case study selected was classified according to its spatial location, parish and province, typology of the sacred architecture, original configuration of the surrounding landscape, symbolic meaning of the place and vegetation associated. All the information was contextualized in a map (Figure 1) and collected in a table (Table 1), thus making it possible to establish similar patterns in the way Christianization modified sacred places throughout the studied territory, and how the different historical layers can still be read in the existing landscapes.

One of the most interesting facts of small religious architecture is that it brings the spiritual message to open spaces and to the landscape (Toth, 2018). The case studies of small architecture range from chapels, churches or small monasteries located in singular places, to architectural or sculptural sets with several elements that configure the space of cult. Some of these elements are repeated throughout the Galician territory and appear generally linked to the same spatial typology, as it is the case of cruceiros and petos de ánimas. These are two paradigmatic elements of small sacred architecture in Galicia that will appear in most of the study cases, therefore a further and more accurate description is needed.

Cruceiros (High cross): legacy of the prehistoric menhirs, the Roman milladoiros and the crosses of the evangelized Ireland of the $6^{\text {th }}$ and $7^{\text {th }}$ centuries. In the classical era they honoured Mercury, protector of travellers, by placing stones in strategic places to form milladoiros. With the arrival of Christianity they were adapted by adding crosses on top.

Petos de ánimas: material manifestation of the cult to the dead. Usually they are small and simple monuments of popular piety associated with the idea of Purgatory. According to the Galician belief, the dead live, awaiting in another place that occupies a different dimension from the world of the living, where time does not pass (Vaqueiro, 2011). Thus, petos de ánimas were built as places to offer alms to these souls of Purgatory, being their temporary punishment and allowing them to reach Heaven. In return, the liberated souls would intercede for those who made the offerings (monetary or agricultural products). These are elements that have been widely studied, usually from a descriptive perspective, both in Portugal (Gonçalves, 1959), and in Spain (Bas, 1980; Menor, 1983). Its origin can be found in the Counter Reformation, being the oldest ones from the $17^{\text {th }}$ century, although the most frequent examples date back to the $18^{\text {th }}$ century. They are made of stone and usually have a cross with images of the souls in the fire of Purgatory and a figure that keeps vigil such as a saint, king or bishop.

\section{Results and discussion}

The study seeks to reveal the importance of landscape as the spatial framework where religious architecture elements appear, taking into special consideration the transformations of these sacred places endured along Christianisation. On that account, landscape transformations have a dual physicalsymbolic nature that implies the apparition of religious architecture elements and the construction of a narrative, or the modification of a previous one, that justifies the sacred character of the place. These changes imply an intention to transmit a symbolic message (the Christian message), easy to interpret, with teaching purposes (Burgoa, 2000), directed to imprint itself in the idiosyncrasy of Galician people, generally ruled by the importance of family, the self-sufficient environment and the limited and difficult communications with the outside world. These conditions created a compendium of beliefs, most of them related to the interweaving of live and death, strengthened by the great connection between people and their land, a bond that reaches the highest level with the death when they are buried and merge into the ground (Pellón, 1997). Being that so, the Christianization process slowly

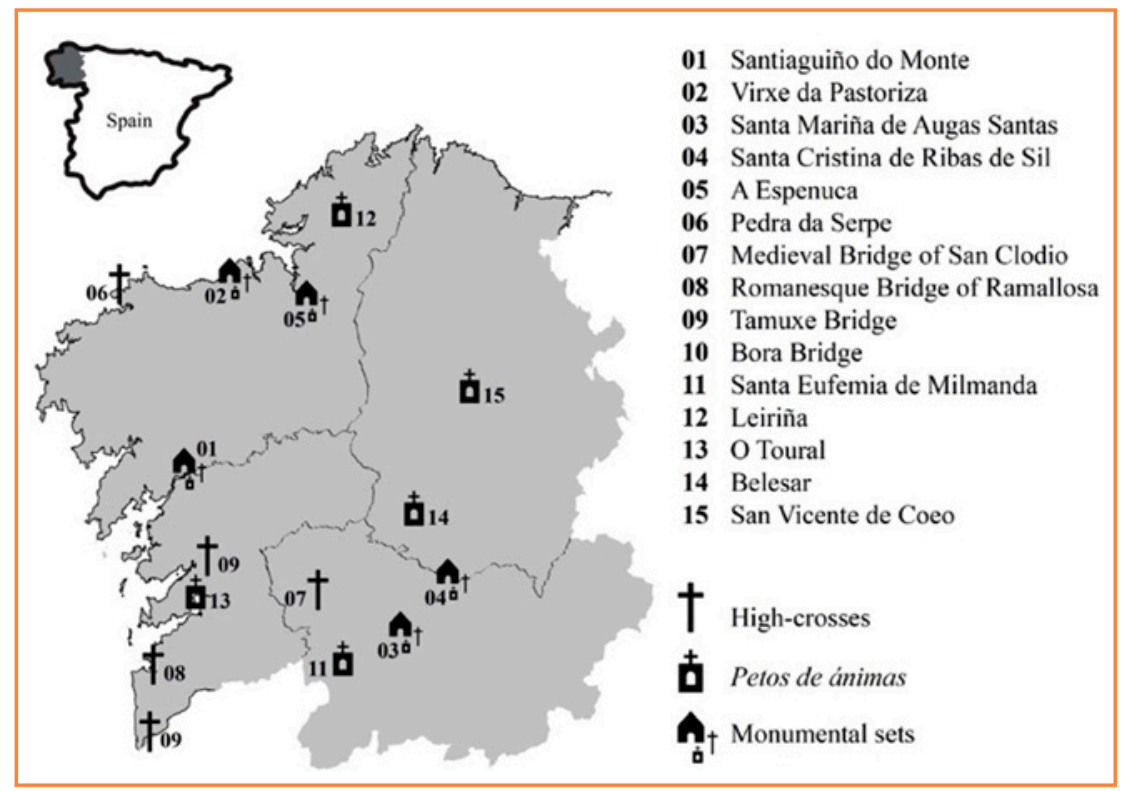

Figure 1 Spatial distribution of the case studies. Galicia (northwest Spain) Source: made by the authors 


\begin{tabular}{|c|c|c|c|c|c|c|c|c|c|c|c|c|}
\hline 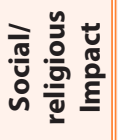 & $\begin{array}{l}\bar{u} \\
\Delta \overline{0} \\
\text { ù }\end{array}$ & 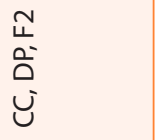 & $\begin{array}{l}\stackrel{m}{\stackrel{m}{F}} \\
\stackrel{\vec{u}}{u}\end{array}$ & $\begin{array}{l}\text { 岀 } \\
\vec{F} \\
\breve{U}\end{array}$ & 崫 & 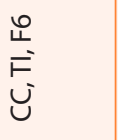 & $\begin{array}{l}\stackrel{\vec{L}}{F} \\
\stackrel{F}{u}\end{array}$ & $\begin{array}{l}\stackrel{\infty}{\llcorner} \\
\stackrel{్}{F} \\
\breve{U}\end{array}$ & $\begin{array}{l}\vec{u} \\
\vec{F} \\
\vec{u}\end{array}$ & 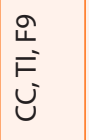 & $\begin{array}{l}\frac{O}{u} \\
\stackrel{u}{E} \\
\text { Ü }\end{array}$ & 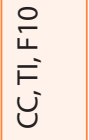 \\
\hline 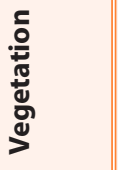 & 岁 & 岂 & 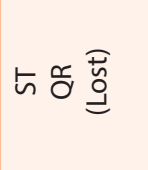 & ๒こ & 岂 & 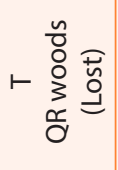 & 1 & 1 & 1 & 1 & 岂 & $\vdash \stackrel{\mathfrak{\sigma}}{0}$ \\
\hline 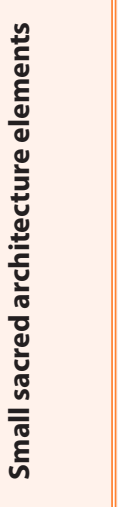 & 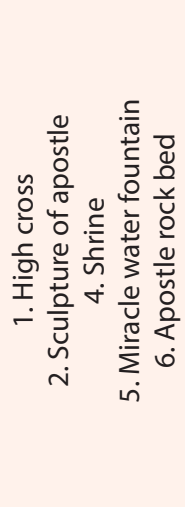 & 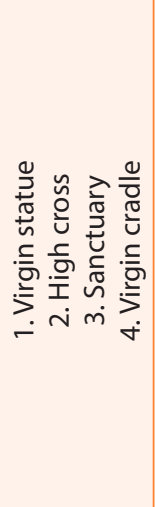 & 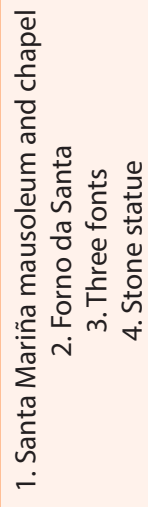 & 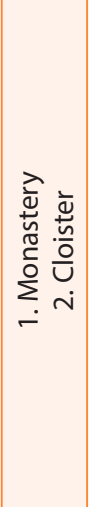 & 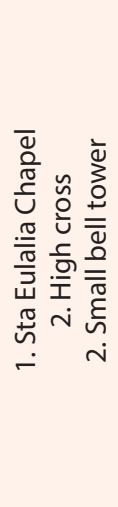 & 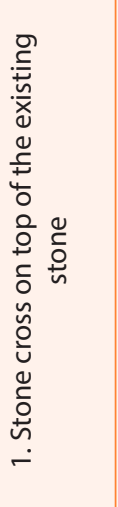 & $\begin{array}{l}\stackrel{\tilde{O}}{\circlearrowright} \\
\stackrel{-}{-}\end{array}$ & 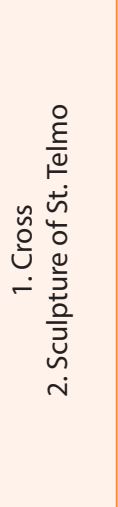 & $\begin{array}{l}\stackrel{u}{0} \\
\stackrel{0}{u} \\
\stackrel{-}{-}\end{array}$ & 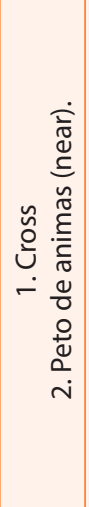 & 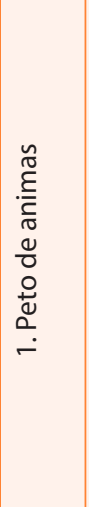 & 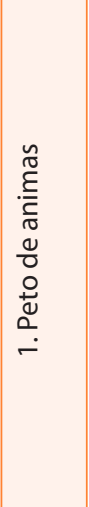 \\
\hline 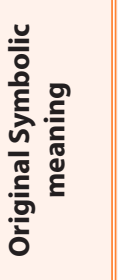 & 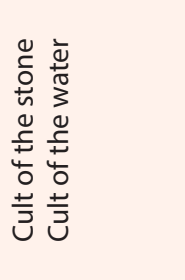 & 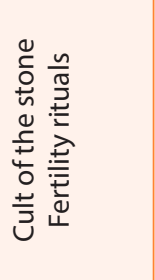 & 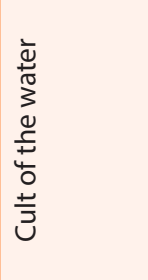 & 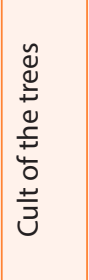 & 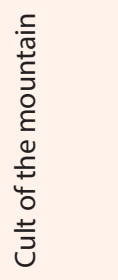 & 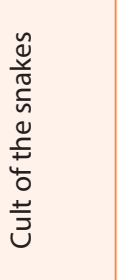 & 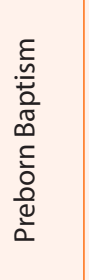 & 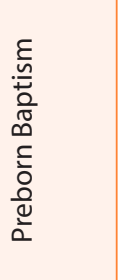 & 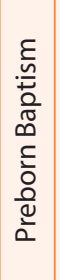 & 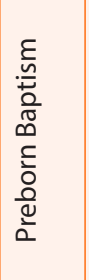 & 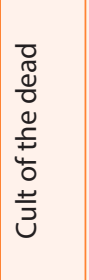 & 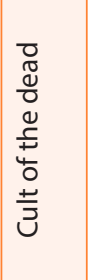 \\
\hline 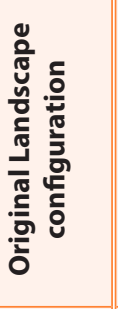 & 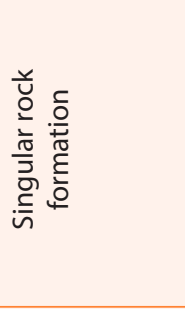 & 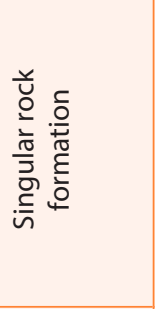 & 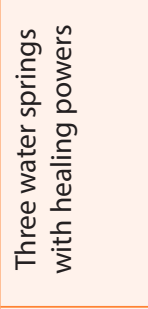 & 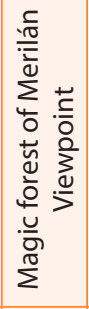 & 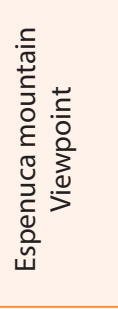 & 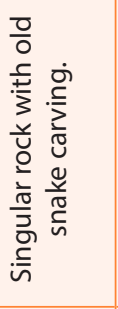 & $\begin{array}{l}\frac{8}{8} \\
\frac{0}{0} \\
\frac{10}{2}\end{array}$ & $\frac{\frac{9}{0}}{\frac{0}{0}}$ & 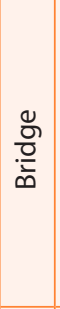 & $\begin{array}{l}\frac{8}{8} \\
\frac{0}{0} \\
\overline{0}\end{array}$ & 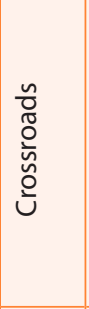 & 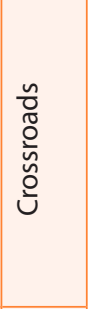 \\
\hline ڤั & 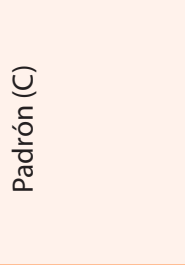 & 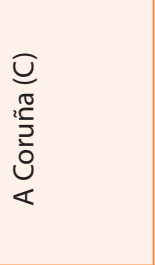 & 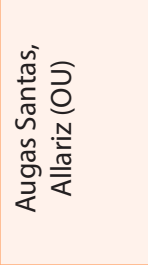 & 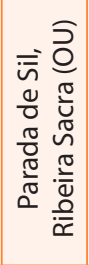 & 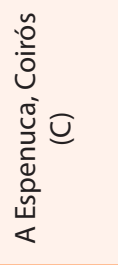 & 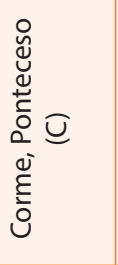 & 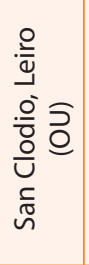 & 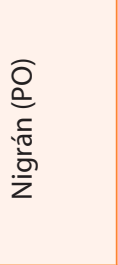 & $\begin{array}{l}\overline{0} \\
\overline{0} \\
\bar{D} \\
\stackrel{0}{0} \\
0 \\
0\end{array}$ & 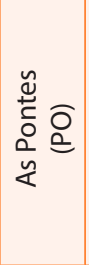 & 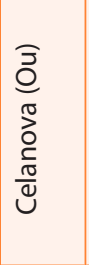 & 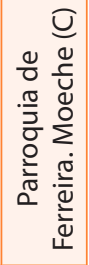 \\
\hline 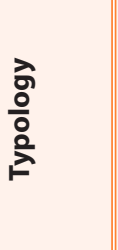 & 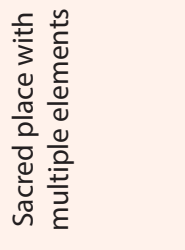 & 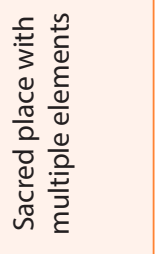 & 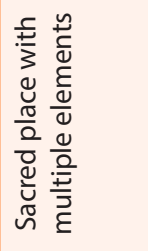 & 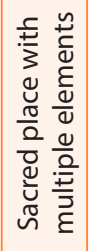 & 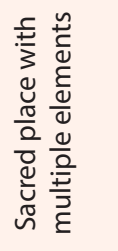 & 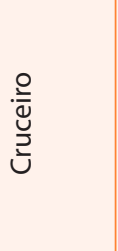 & 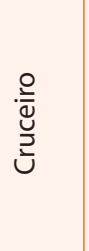 & 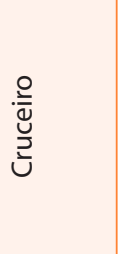 & 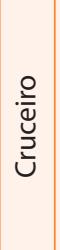 & 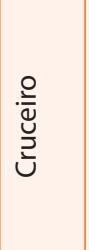 & 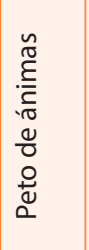 & 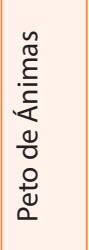 \\
\hline 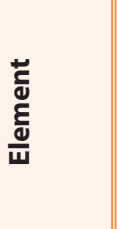 & 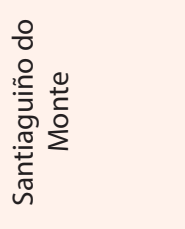 & 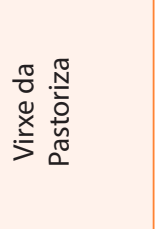 & 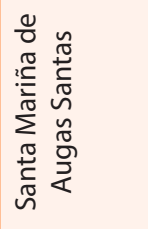 & 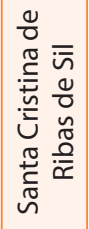 & 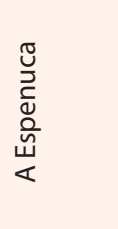 & 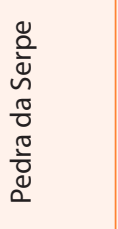 & 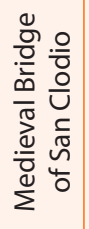 & 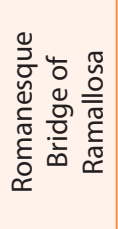 & 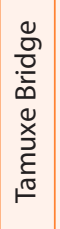 & 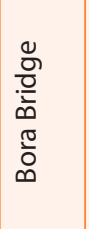 & 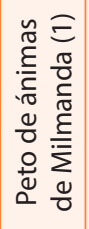 & 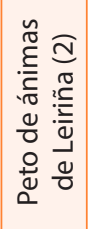 \\
\hline z & - & $N$ & $m$ & 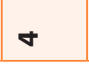 & in & 0 & $\wedge$ & & $a$ & 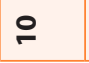 & $=$ & $\simeq$ \\
\hline
\end{tabular}




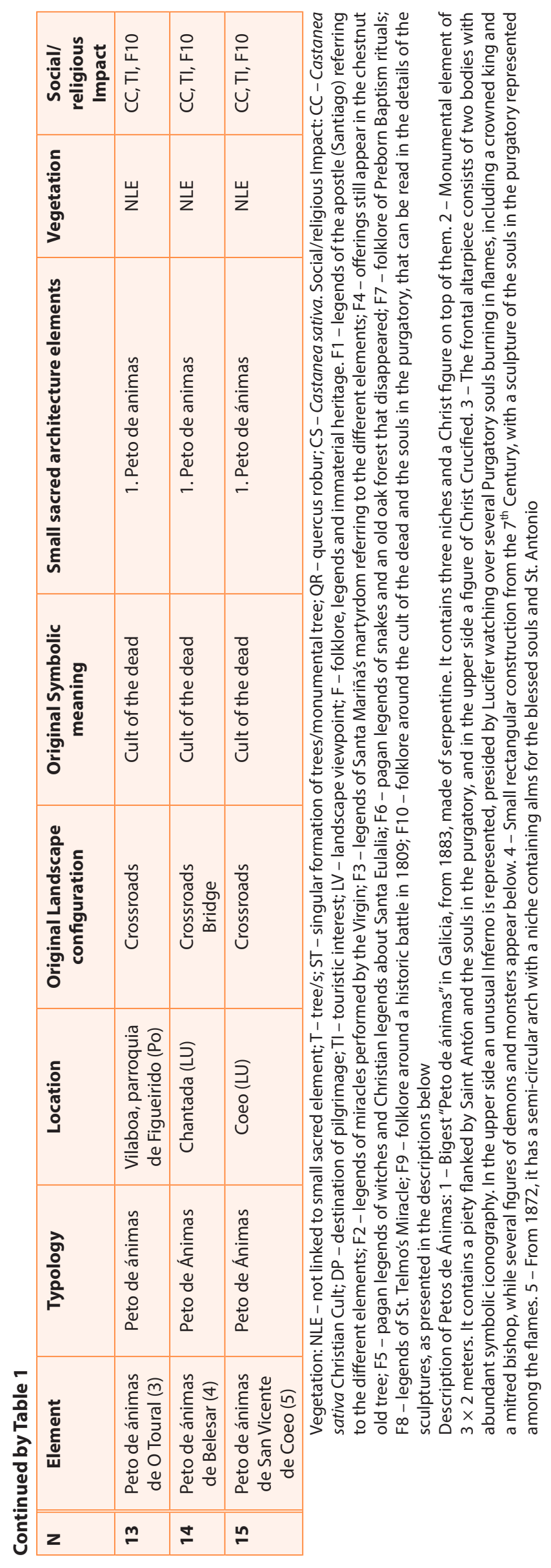



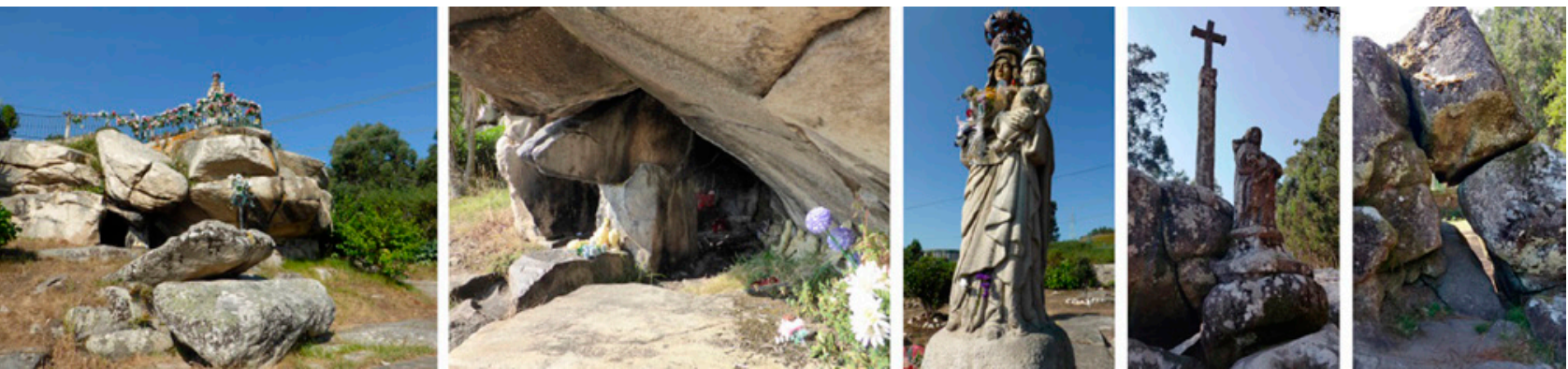

Figure 2 Monte da Pastoriza (to the left) and Santiaguiño do Monte, 2018 Source: made by the authors
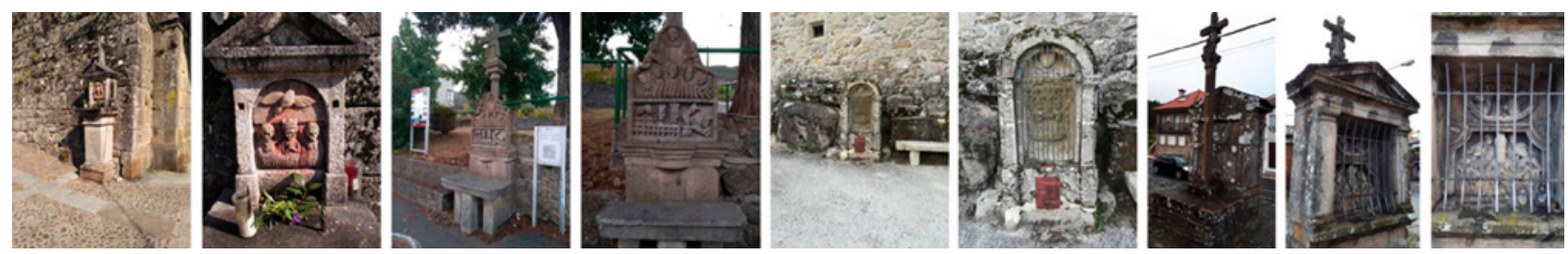

Figure 3 Examples of Petos de ánimas in Galicia, 2018 Source: made by the authors

adapted the pagan sacred places and the folklore around them, taking into account that the presence of the dead in Galician traditional life has been an element of prime importance, with spatial-temporal constraints (Menor, 1983). The use of small architecture elements, very common in Galicia, provides structure to a landscape with a character and identity that blend perfectly with the vegetation and the territory morphology.

The classification of the case studies, presented in Table 1 , allows us to identify common patterns in the way sacred places were managed all over the Galician territory. Three different typologies were identified: sacred places with multiple elements that create a monumental set, Cruceiros (High crosses), and Petos de Ánimas. The original landscape configuration and meaning columns collect both physical remains and symbolic interpretations extracted from folklore. They provide evidence on the sacred character of each case study, previous to the arrival of Christianism. The small sacred architecture elements column refers to the physical process of Christianization, usually by adding stone crosses, while the social religious impact column collects the symbolic transformation, recording the folklore legends, as well as the interest (touristic, pilgrimage...) of each place. The vegetation column registers the existence of certain trees and plants linked to small sacred architecture, so important from the landscape architecture point of view, but also for its sacred meaning and symbolism.

Every case study shows the transformation of both physical and symbolic landscape dimensions through the Christianization process. This way, in Monte da Pastoriza, there are traces of old singular rock formations that, according to popular legends and ethnographical studies, are related to ancient fertility rituals and pagan cults to the stones. The Christianization process implied the creation of a narrative about the apparition of the Virgin, and the construction of a temple and a sculpture. The same thing happens in other places of pilgrimage, some of them in The way of St. James, as in the case of Santiaguiño do Monte in
Padrón, a singular space with rock formations and water springs considered magical for its medicinal properties, which indicates the existence of ancient cults to the divinities of water and rocks. The Christianization is carried out by the construction of a High-cross and a statue, assuming this was the altar where St James used to preach.

This sort of monumental sets articulated through a legend are very frequent, as in the case of Santa Mariña de Augas Santas, where the whole village is built around the legend of the martyrdom of the saint. "The legend of Santa Mariña adheres to the territory like a mantle of narrative that covers it and gives it meaning" (García Quintela, 2014). Thus, the place awakened a touristic interest through the visits to the different elements such as the three miracle springs or the disappeared Carballo da Santa, an old oak tree that takes part in the tale, representing perfectly the symbolism of some tree species regarding sacred spaces. "When the Christian missionaries undertook the conversion of the pagan peoples, one of their first actions was to prohibit the worship of trees and destroy the sacred forests" (Fischesser, 1995). This phenomenon is evident in Santa Cristina de Ribas de Sil where an ancient chestnut tree contains offerings hanging from their branches, due to the ancient pagan cult that still remains. Many places linked to pre-Christian rituals were converted to Christianism by adding a Cruceiro or peto de ánimas. That is the case of Pedra da Serpe and many high-crosses located on bridges where the traditional ritual of bautismo anticipado' used to take place. The same occurs with petos de ánimas located in crossroads where, according to folklore, the veil between this world and the

\footnotetext{
1 Bautismo anticipado (in English preborn baptism) is a traditional Galician ritual that was performed before the birth took place, in order to guarantee its success. For this purpose, the family members should go to the designated bridge and wait for a person to cross it. Then, they had to convince him (it had to be a man) to help them with the ritual, and if he agreed and everything went as it was expected, he would become the godfather of the child.
} 
supernatural drops, allowing phenomena such as the Compaña ${ }^{2}$ to manifest. Small sacred architecture appears to Christianise these places.

\section{Conclusion}

Galicia is a region with a clear historical relation between landscape, religion (pre-Christian and Christian cults) and society, and houses a large number of small sacred architecture. The analysed case studies show how the process of re-writing landscape (Pracero et al., 1998) over the years has resulted into complex spaces where many layers of history can be read. As it was demonstrated, the apparition of small sacred architecture elements is usually linked to the existence of a singular landscape imbued with a previous sacred meaning that can still be read through some remaining natural elements as well as the folklore around them. However, these landscapes endured a great change with the arrival of Christianity, which modified both its physical form through the construction of architecture and sculpture elements, and its symbolic narrative, adapting the existing myths, legends and tales to the Christian doctrine. Trees and all sorts of vegetation have also been sacred elements of veneration, as well as elements of accompaniment to some sacred religious structures. The arboreal vegetation that was identified consists mainly of Quercus robur and Castanea sativa, and its use linked to sacred elements has continued until our time. Yet nowadays, it appears only in $26 \%$ of the case studies (4/15), indicating that small sacred architecture in Galicia is based in the direct lecture of the anthropic religious constructions, independently from the linked vegetation.

The evolution of sacred landscapes through the different eras has changed the meaning and use of these spaces, maintaining sometimes its religious character, as is the case of the many destinations of pilgrimage, but they also bear a cultural and touristic interest nowadays. The study of the these multi-layered spaces from a landscape architecture point of view is essential to guarantee their conservation and ultimately preserve the identity and the genius loci of every one of them, for they are a fundamental part of the European cultural heritage.

\section{References}

BAS LÓPEZ, B. 1980. Construcciones populares galegas. Coruña. S.I. Bankunión, imp.

BURGOA FERNÁNDEZ, J. J. 2000. El patrimonio etnográfico y el arte popular: cruceros y petos de ánimas de los municipios de Moeche y San Sadurniño. In An. Brigantino, vol. 23, 2000, pp. 477-494.

GONÇALVES, F. 1959. Os painéis do Purgatório e as origens das alminhas populares. In Boletim da Biblioteca Municipal de Matosinhos, 1959, no. 6, pp. 78-79.

FISCHESSER, B. 1995. Connaître les arbres (Editorial El Drac, S. L. Trans.). Paris : Ed Nathan, 1995.

GARCÍA QUINTELA, M. V. 2014. Paisajes duales en la galicia tradicional: Estructura, génesis y transformación. Dual Landscapes in Traditional Galicia : Structure, Genesis, and Transformation. In Revista De Dialectología Y Tradiciones Populares, vol. LXIX, 2014, no. 1, pp. 29-30-52.

LISÓN TOLOSANA, C. 1974. Perfiles simbólico-morales de la cultura gallega. Ed. Akal, S.A., 1974.

MENOR CURRÁS, M. 1983. Los Petos de ánimas de la provincia de Orense. In Folklore, 1983, 25.

NORBERG-SCHULZ, C. 1980. Genius loci, towards a phenomenology of architecture. Rizzoli, 1980.

PELLÓN REVUELTAS, S. 1997. Los petos de ánimas de Ourense. Narria 79-80: 1-6. Museo de artes y tradiciones populares de la universidad autónoma de Madrid, 1997.

PRACERO, C. - CRIADO, F. - SÁNTOS, M. 1998. Rewriting landscape: Incorporating sacred landscapes into cultural traditions. In World Archaeology, vol. 30, 1998, no. 1, pp. 159-160-176.

ROGER, A. 1997. Court traité du paysage. Paris : Éd. Gallimard, 1997. VAQUEIRO, V. 2011. Mitoloxía de galicia. lendas, tradicións, maxias e milagres. Ed. Galaxia, 2011.

TÓTH, A. - VEREŠOVÁ, M. 2018. Small Sacral Architecture and Trees as Monuments in Diverse Cultural Landscapes of Slovakia. In Plants in Urban areas and landscape. International Scientific Conference Proceedings, 2018, pp. 7-13.
2 Compaña, also known as Santa Compaña, is one of the most famous folklore myths in Galician territory, linked to the mystery of Death. The multiple accounts of sightings of Compaña refer to it as a procession of dead spirits carrying a candle, that usually appear in crossroads and other sacred places. 